\title{
ANATOMICAL, MORPHOLOGICAL CHARACTERS AND YIELD AND ITS ATTRIBUTES OF SOME RICE VARIETIES (ORYZA SATIVA L.) TREATED WITH X RAYS
}

\author{
EI- EMARY, F.A' ${ }^{1}$., M.I. ABO- YOUSSEF ${ }^{2}$, I.A.TALHA ${ }^{2}$ AND W. \\ H. EL-KALLAWY'. \\ 1- Dept. Of Agric Botany, Fac.Of Agric. Assiut, AL- AzharUniv; \\ Egypt.2- Rice research section, FCRI, ARC, Egypt
}

\begin{abstract}
This study was conducted at the farm of Rice Research Section, FCRI, ARC and Agric. Botany department, Fac. of Agricultural, Assiut, AlAzhar Univ., Egypt. During 2015 and 2016 summer seasons in randomized complete block design with three replications, to study the effect of treated with (350 $\mathrm{Kr} X$ rays) on anatomical, morphological and yield characters in some rice varieties viz, Sakha 101, Sakha 104, Giza 177 and Giza 178 with their mutants. The data were recorded on : 1- Anatomical characters i.e, diameter of root, epidermis thickness, cortex thickness, diameter of vascular cylinder, (meta xylem vessels and number of xylem vessels). 2- Morphological characters i.e, days to heading, plant height, no. of tillers per plant, total chlorophyll content in the leaves and 3- Yield components i.e,, no. of panicles/plant, panicle length, panicle weight, no. of total grains/panicle, 1000 grain weight, seed set \%, grain yield per plant and harvest index. The results showed that, highly differences were found of diameter and numbers of xylem vessels in vascular cylinder especially with Sakha 101 and Giza 178 by using $X$ - rays. Moreover, there are wider of diameter of root, vascular cylinder and cortex thickness were shown in all treated varieties except Giza 178 compared to untreated plant. Indicating enhancement the morphological characters, days to heading, plant height and number of tillers except total chlorophyll content in the leaves. As well as, enhancement of yield and it is components, panicle characters, 1000 grain weight, seed set\% ,grain yield and harvest index\% compared to un treated varieties. Which are considered as a promising varieties compared to original rice varieties (un treated). So, this investigation recommended to using this treatment ( $350 \mathrm{kr}$ of $\mathrm{X}$ rays) with these varieties to improve anatomical, morphological characters and productivity under the same field conditions. Finally, we advices use this treatment with some rice varieties and testing to high yielding and tolerance of up normal conditions (salinity, drought and ect.)
\end{abstract}

Key words:- Root anatomical structure- Rice varieties - X rays.

\section{INTRODUCTION}

Rice (Oryza sativa, L.) is considered as one of the most important cereal crops not only in Egypt, but also in all over the world. 
The yearly cultivated area by rice is almost more than one fifth of the total area. The total cultivated area of rice was about 0.600 million ha, which produced 6.174 .00 tons of paddy rice with an average of 4.095 t/ha.(RRTC, 2015).

For any improvement for the traits the genetic variability is required. Induced mutations with the discovery of array of radiation mutagen and improvement treatments methods offer possibility for the induction of desired changes in various attributes, which can be exploited as much or through recombination breeding Akbar and Manzoor (2003) and Khin (2006). More than 2200 crop varieties were released by the end of the last century using irradiation mutagenesis, among them 434 are rice varieties Elayarajaet al. (2005), Wu et.al. (2005) and Mohamadet.al.(2006). Mutagen agents, including gamma rays, offered great possibilities for increasing genetic variability of quantitative traits like yield. Mutation breeding in rice was established in Egypt since 1960. Also, using rice root anatomical structure as indicator to exhibited variance in root structure will be helpful the plant breeder for screening breeding materials in early germination stage on the bases, number of xylem vessels and diameter of root. So, the main objectives of this study was using the $X$ rays with anatomical root, morphological and yield characters to differentiation among some rice varieties and estimate simple correlation coefficients among their characters.

\section{MATERIALS AND METHODS}

\section{A-Field Experiments:}

The seeds of Sakha 101, Sakha 104, Giza 177 and Giza 178 were treated since 2007 season with different doses of $X$ - rays radiation at the rate of , 200, 250, 300 and 350 Kilo rad (Kr). The dose of X- ray radiation at the rate of $350 \mathrm{Kr}$ produced mutants from the treated cultivars under study i.eSakha 101, Sakha 104, Giza 177 and Giza 178. The mutants were planted year after year with make selection and purification until reached to $F_{n}$ generation.

The seeds of previously mentioned cultivars and their mutants were used in the current investigation and sown at the farm of Rice Research and Training Center (RRTC), Sakha, Kafr El-Sheikh, Egypt collaborated with laboratory of Agric. Botany department, Faculty of agricultureAssuit, El- Azhar University during two 2015 and 2016 successive seasons.

The aim of this investigation is to study the impact of $X$ - rays radiation on anatomical, morphological characters and yield and its attributes of some rice cultivars. The date of sowing was in May first in the two studied seasons in the prepared nursery then transplanted in the permanent field after 30 days from sowing in complete randomized 
block design with three replications. All the culture practices were done as recommendations described by (RRTC,2014)

The data were recorded on anatomical, morphological and yield characters as recommended by Standard Evaluation System (SES) of IRRI 1998.

A-Anatomical studies: Root samples were taken at transplanting (35 days from sowing) during 2016 summer season to study the anatomical characteristics i.e, diameter of root $(\varnothing \mathrm{r})$, epidermis thickness, cortex thickness, diameter vascular cylinder ( $\varnothing \mathrm{vc}$ ), diameter of meta xylem vessels $(\varnothing \mathrm{Mxv})$ and number of xylem vessels, Anatomical study one of the way to select the best rice varieties, ten samples of root per plot were collected. Each sample measured $0.5 \mathrm{~cm}$ of the tip portion of the root (Radical root tip). All samples were killed and fixed for 48 hours in FAA (10 ml. formalin, $5 \mathrm{ml}$. glacial acetic acid, $50 \mathrm{ml}$. ethyl alcohol and $35 \mathrm{ml}$. water). The dehydrated samples were infiltrated and embedded in paraffin $\left(52-54^{\circ} \mathrm{Cm}\right.$.p.). The embedded samples were sectioned on a rotary microtome at a thickness of 5-7 $\mu \mathrm{m}$. Sections were mounted on slides and deparaffinized. Staining was accomplished with safranine and light green, cleared in xylol and mounted in Canada balsam (Gerlach, 1977). Slides were microscopically examined and measurements and counts were taken and averages of 9 readings of 3 slides were calculated. The sections were computerized anatomical analysis was done by Research Microscope type Axiostar plus made by Zeiss transmitted light bright field examinations apgrad able to professional digital image analysis system (Carl Zeiss Axiovision Product Suite DVD 30).

B- Morphological charactersi.e, Number of days from sowing to heading, plant height, no. of tillers per plant and total chlorophyll content in leaves before heading (SPAD).

C- Grain yield and its attributes i.e, Number of panicles per plant, panicle length, panicle weight, no. of total grain per panicle, 1000 grain weight, seed set, grain yield per plant, harvest index $\%$.

Statistical analysis: The statistical analysis of variance for randomized complete block design (RCBD) was done as described by Steel and Torrie (1980) using COSTAT computer software package.

\section{RESULTES AND DISCUSSION}

Data in Table. (1) and Fig.(1) represent transverse root sections from tip roots. The data releaved that there were adifferent arrangements of bundles' number and diameter of vessels in xylem arch in vascular cylinder of rice roots among the tested cultivars and their mutants. Larger of diameter of vascular cylinder with the mutants of Sakha 104, Giza 177 and Sakha $101(134.45,125.88$ and 105.90( $\mu)$ respectively, were found anatomical characters in root of some rice 
cultivars and their mutants i.e, diameter of root, epidermis thickness, cortex thickness, diameter of vascular cylinder, diameter of meta xylem and number of xylem vessels are presented in Table (1). Data demonstrated that Sakha 104 mutants gave higher value in all the previously mentioned anatomical characters than the untreated Sakha 104 cultivar expect diameter of meta xylem and number of xylem vessels, followed by Sakha 101 mutant which had also higher values in all the tested anatomical characters than the untreated Sakha 101 cultivar expect epidermis thickness and number of xylem vessels, it can be easly observed that all the mutants under study had the greatest value in the diameter of vascular cylinder expect Giza 178 mutant which gave the lowest value in this aspect. The data in the same table clarified that Giza 178 cultivars more sensitive to X- ray radiation than the other tested cultivars. These results agreed with those obtained by Kawate et al (1979) and Sabbour et al (1993). They proved that, the diminution of vascular system in the root is an quite important factor regarding their function. Also, the results are in a harmony with those obtained by Denise (2003), he recorded that, cortex tissues of parenchyma added arenchyma a specialized tissue with abundant interconnected gas spaces is common in the roots and shoots of many emergent wetland plant like rice (semi- aquatic plant).

Table (1): Mean performance of anatomical characters of some rice cultivars and their mutants at seedling stage (35 days from sowing date) in 2016 season

\begin{tabular}{|c|c|c|c|c|c|c|}
\hline Varieties & $\varnothing r$ & Ep. thickness & $\begin{array}{c}\text { Cort. } \\
\text { thickness }\end{array}$ & Vc. Cylinder & $\begin{array}{l}\text { M. X. } \\
\text { Vessels }\end{array}$ & No. X. Vessels \\
\hline $\begin{array}{l}\text { SakhA } 101 \\
\text { SakhA } 101 M^{*} \\
\text { Sakha } 104 \\
\text { Sakha } 104 M^{*} \\
\text { Giza } 177 \\
\text { Giza } 177 M^{*} \\
\text { Giza } 178 \\
\text { Giza } 178 M^{*}\end{array}$ & $\begin{array}{l}348.56 \\
541.14 \\
281.81 \\
724.21 \\
464.26 \\
407.67 \\
404.37 \\
212.07 \\
\end{array}$ & \begin{tabular}{l|}
10.71 \\
10.59 \\
12.70 \\
15.10 \\
14.30 \\
13.10 \\
13.00 \\
5.50 \\
\end{tabular} & $\begin{array}{l}236.14 \\
424.65 \\
177.17 \\
574.66 \\
359.62 \\
286.69 \\
287.51 \\
151.15 \\
\end{array}$ & $\begin{array}{c}101.71 \\
105.90 \\
91.84 \\
134.45 \\
85.75 \\
125.88 \\
103.86 \\
55.42 \\
\end{array}$ & $\begin{array}{l}18.13 \\
45.20 \\
57.11 \\
30.12 \\
39.11 \\
42.00 \\
42.91 \\
14.10\end{array}$ & $\begin{array}{c}12.00 \\
4.00 \\
3.00 \\
4.00 \\
5.00 \\
5.00 \\
5.00 \\
10.00\end{array}$ \\
\hline LSD 0.05 & 19.91 & 0.055 & 1.119 & 0.146 & 0.056 & 0.303 \\
\hline
\end{tabular}

${ }^{*} \mathrm{M}=$ Mutant in $\mathrm{F}_{\mathrm{n}}$ generation

** $\varnothing \mathrm{r}=\mathbf{0 . 5}$ Diameter of root

${ }^{\star * *}$ V.C $\varnothing \mu=0.5$ Diameter of Vascular cylinder

${ }^{* * \star *}$ M. X. V = 0.5 Diameter of meta xylem vessels

Data in Table (2) showed that there were highly significant differences among all varieties under study in the values of diameter of root, epidermis, cortex thickness, vascular cylinder, meta Xylem Vessels and Number of Xylem Vessels. Data also revealed that the heritability in broad sense recorded the highest values in root characters; It means that there were highly significant differences between the mutants and their parents in genetic constitution due to the $\mathrm{X}$ - ray treatments only without any effect by environmental condition. These results were confirmed with those obtained by El- 
Emery et al., (2015) they found that, larger of vascular bundles with treated CMS line IR69625A improved the growth and yield as well as the quality of grains as the results to increase the absorption of soil water and nutrients uptake.

Table (2): Estimates of the mean square of anatomical characters of some rice cultivars and their mutants that produced from X- rays treatment at seedling stage ( 35 days from sowing date) during 2016 season

\begin{tabular}{|c|c|c|c|c|c|c|}
\hline S.O.V & $\begin{array}{c}\text { Diameter } \\
\text { of root }\end{array}$ & $\begin{array}{c}\text { Epidermis } \\
\text { thickness } \\
(\mu)\end{array}$ & $\begin{array}{c}\text { Cortex } \\
\text { thickness } \\
(\mu)\end{array}$ & $\begin{array}{c}\text { Vascular } \\
\text { cylinder } \\
R=\varnothing \mu\end{array}$ & $\begin{array}{c}\text { M. Xylem } \\
\text { Vessels } \\
(\varnothing)\end{array}$ & $\begin{array}{c}\text { Number } \\
\text { of } \\
\text { Xylem } \\
\text { Vessels }\end{array}$ \\
\hline $\begin{array}{l}\text { Replication } \\
\text { Genotypes } \\
\text { Error }\end{array}$ & $\begin{array}{c}345.042 \mathrm{~ns} \\
81659.39^{\star *} \\
344.65\end{array}$ & $\begin{array}{c}0.002 \mathrm{~ns} \\
27.30^{\star *} \\
0.01\end{array}$ & $\begin{array}{c}5.70 \mathrm{~ns} \\
58360.20^{*} \\
* \\
4.108\end{array}$ & $\begin{array}{c}0.504 \mathrm{~ns} \\
1780.15^{\star \star} \\
0.507\end{array}$ & $\begin{array}{c}0.220 \mathrm{~ns} \\
624.50^{\star *} \\
0.501\end{array}$ & $\begin{array}{c}0.038 \mathrm{~ns} \\
30.86^{\star \star} \\
0.030\end{array}$ \\
\hline $\begin{array}{l}\mathrm{H} 2_{\mathrm{b}} \\
\mathrm{C} . \mathrm{V}\end{array}$ & $\begin{array}{c}99.16 \\
4.43\end{array}$ & $\begin{array}{l}99.96 \\
0.267\end{array}$ & $\begin{array}{l}99.98 \\
0.206\end{array}$ & $\begin{array}{l}99.94 \\
0.083\end{array}$ & $\begin{array}{l}99.88 \\
0.056\end{array}$ & $\begin{array}{l}99.78 \\
2.885\end{array}$ \\
\hline
\end{tabular}

Data in Table (3) clarified that there were a significant differences among the tested cultivars and their mutants in some morphological characters namely number of days to heading, plant height, number of tillers and chlorophyll content. The mutants caused a decrease in number of days to heading, the tall of plant and chlorophyll content than their parents. On contrast the same tested mutants significantly increased the number of tillers per plant. It means that the mutants which produced from the treated cultivars under study by Xrays radiation had less duration and tall of plant as well as chlorophyll content while had more number of tillers than their parents, by the other meaning, treated the cultivars under study by $(350 \mathrm{Kr}) \mathrm{X}$ - rays radiations produced mutants had desirable morphological characters as the results to exchange in genetic structure or constitution. These results were hold true in the two studied seasons, the result was obtained by Pillaiet al (1993) they found that, Gamma-rays were more effective for inducing viable mutants.

Table (3): Mean performance for some morphological characters of different rice cultivars and their mutants that produced from X- ray treatment during 2015 and 2016 seasons

\begin{tabular}{|l|c|c|c|c|c|c|c|c|}
\hline \multirow{2}{*}{ Varieties } & \multicolumn{2}{|c|}{$\begin{array}{c}\text { Days to heading } \\
\text { (Day) }\end{array}$} & \multicolumn{2}{c|}{ Plant height (cm) } & \multicolumn{2}{c|}{ No. of tillers/ plant } & \multicolumn{2}{c|}{$\begin{array}{c}\text { Chlorophyll content } \\
\text { (SPAD) }\end{array}$} \\
\cline { 2 - 9 } & 2015 & 2016 & 2015 & 2016 & 2015 & 2016 & 2015 & 2016 \\
\hline Sakha 101 & 107.00 & 106.33 & 94.33 & 94.31 & 22.25 & 22.59 & 45.15 & 45.63 \\
Sakha 101M & 104.33 & 103.67 & 93.00 & 93.04 & 24.00 & 25.34 & 42.86 & 43.37 \\
Sakha 104 & 100.83 & 99.67 & 106.39 & 107.64 & 23.34 & 23.69 & 44.82 & 45.25 \\
Sakha 104M & 97.67 & 96.00 & 100.00 & 95.83 & 24.26 & 24.50 & 43.45 & 43.78 \\
Giza 177 & 90.33 & 91.12 & 107.17 & 109.50 & 23.71 & 23.67 & 42.02 & 42.89 \\
Giza 177M & 96.00 & 96.33 & 105.54 & 106.11 & 24.26 & 24.82 & 38.26 & 38.70 \\
Giza 178 & 101.33 & 100.33 & 106.20 & 103.90 & 23.40 & 23.19 & 44.07 & 44.64 \\
Giza 178M & 97.67 & 97.67 & 100.33 & 101.85 & 25.81 & 24.03 & 41.20 & 42.72 \\
\hline LSD 0.05 & 0.889 & 1.260 & 1.019 & 1.184 & 1.254 & 1.272 & 0.332 & 0.210 \\
\hline
\end{tabular}


Data in Table ( 4 ) showed that highly significant differences among all the varieties under study in the studied morphological characters were observed for days to heading, plant height, number of tillers/plant and chlorophyll content, as well as, the heritability in broad sense. It could be attributed to the exchanges in the genetic structure a constitutions which cause a significant differences in the morphological characters among the mutants produced $X$ - ray treatment and their parents. It can be noticed that there was any environmental effect on previously mentioned characters by the other meaning the effect in these characters due to X- ray treatment only. These results were in harmony with those obtained by sanjeev (2000) who found that many early maturing and semi dwarf rice lines were produced using gamma radiation treatments.

Table (4): Estimates of the mean square of some morphological characters of different rice cultivars and their mutants that produced from X- ray treatment during 2015 and 2016 seasons

\begin{tabular}{|l|c|c|c|c|c|c|c|c|}
\hline \multirow{2}{*}{ S.O.V } & \multicolumn{2}{|c|}{$\begin{array}{c}\text { Days to heading } \\
\text { (Day) }\end{array}$} & \multicolumn{2}{c|}{ Plant height (cm) } & \multicolumn{2}{c|}{ No. of tillers } & \multicolumn{2}{c|}{$\begin{array}{c}\text { Chlorophyll } \\
\text { content (SPAD) }\end{array}$} \\
\cline { 2 - 9 } & 2015 & 2016 & 2015 & 2016 & 2015 & 2016 & 2015 & 2016 \\
\hline Replicatio & $0.45 \mathrm{~ns}$ & $0.38 \mathrm{~ns}$ & 0.92 & $0.23 \mathrm{~ns}$ & $1.00 \mathrm{~ns}$ & 0.86 & $0.01 \mathrm{n}$ & $0.01 \mathrm{n}$ \\
$\mathrm{n}$ & $119.14^{*}$ & $129.09^{*}$ & $\mathrm{~ns}$ & $131.16^{*}$ & $6.53^{* *}$ & $\mathrm{~ns}$ & $\mathrm{~s}$ & $\mathrm{~s}$ \\
Genotype & & & $93.28^{*}$ & & 0.51 & $16.96^{*}$ & $14.91^{*}$ & $14.14^{*}$ \\
$\mathrm{~s}$ & 0.26 & 0.52 & & 0.46 & & & & \\
Error & & & 0.34 & & & 0.53 & 0.04 & 0.01 \\
\hline $\mathrm{H}_{2} \mathrm{~b}$ & 99.41 & 99.31 & 98.37 & 99.48 & 81.22 & 92.43 & 99.67 & 99.96 \\
C.V & 0.51 & 0.75 & 0.57 & 0.66 & 3.52 & 3.42 & 0.44 & 0.28 \\
\hline
\end{tabular}

* and ${ }^{* *}$ significant or highly at 0.05 .

Data in Table (5) showed that there were highly significant differences among mutants varieties i.eSakha $101 \mathrm{~m}$, Sakha $104 \mathrm{~m}$, Giza $178 \mathrm{~m}$ and Giza $177 \mathrm{~m}$ were found and recorded the desirable values for yield attributes namely number of panicles/plant, panicle weight and total of grains per panicle, the in consist values among the total cultivars were recorded in the length panicle compared to their parents, it may be referred to the new recombination's of the rice varieties after treated by $\mathrm{X}$ ray with $350 \mathrm{Kr}$. These results were agreement with those obtained by Hammad and El-Geddawi (1988) they found that, irradiating seeds with a suitable dose of gamma rays produces physiological or genetical changes in plant tissue which may affect the yield of plant. 
Table (5): Mean performance for yield attributes of some rice cultivars and their mutants that produced from X- ray treatment during 2015 and 2016 seasons

\begin{tabular}{|l|c|c|c|c|c|c|c|c|}
\hline \multirow{2}{*}{ Varieties } & \multicolumn{2}{|c|}{$\begin{array}{c}\text { No. of Panicles } \\
\text { plant }^{-1}\end{array}$} & \multicolumn{2}{c|}{$\begin{array}{c}\text { Panicle length } \\
(\mathrm{cm})\end{array}$} & \multicolumn{2}{c|}{$\begin{array}{c}\text { Panicle weight } \\
(\mathrm{g})\end{array}$} & \multicolumn{2}{c|}{ Total grains panicle $^{-1}$} \\
\cline { 2 - 9 } & 2015 & 2016 & 2015 & 2016 & 2015 & 2016 & 2015 & 2016 \\
\hline Sakha 101 & 19.72 & 18.70 & 24.17 & 24.18 & 4.20 & 4.82 & 151.97 & 168.68 \\
Sakha 101M & 20.78 & 19.20 & 23.33 & 24.42 & 4.38 & 5.24 & 153.97 & 171.17 \\
Sakha 104 & 14.87 & 19.04 & 22.33 & 23.00 & 4.07 & 4.53 & 148.67 & 149.33 \\
Sakha 104M & 16.87 & 20.92 & 23.00 & 21.82 & 4.18 & 4.37 & 156.25 & 161.01 \\
Giza 177 & 17.73 & 17.63 & 21.53 & 21.37 & 4.07 & 4.26 & 140.73 & 145.64 \\
Giza 177M & 18.42 & 19.87 & 22.00 & 20.42 & 4.17 & 4.53 & 142.79 & 147.50 \\
Giza 178 & 17.83 & 17.36 & 22.81 & 22.39 & 4.48 & 4.65 & 190.40 & 194.50 \\
Giza 178M & 19.72 & 18.50 & 22.82 & 22.73 & 4.75 & 5.03 & 196.00 & 197.25 \\
\hline LSD 0.05 & 1.130 & 0.558 & 0.516 & 0.469 & 0.072 & 0.129 & 2.234 & 3.470 \\
\hline
\end{tabular}

Data in Table (6) showed that, highly differences among all varieties under study were found. The rice varieties gave highly significant values in number of panicles/plant, panicle length and weight and total grains/panicle, as well as, the heritability in broad sense. It could be attributed to the differences in the genetic background between the mutants and their parents. Although these characters didn't affect by environmental conditions. These results were confirmed with those obtained by Fujii and matsumura (1958) they found that, sensitivity to radiation widely varied not only among different species but also among different commercial varieties within the same spices.

Table (6): Estimates of the mean square of yield attributes of some rice cultivars and their mutants that produced from X- rays treatment during 2015 and 2016 seasons

\begin{tabular}{|c|c|c|c|c|c|c|c|c|}
\hline \multirow[t]{2}{*}{ S.O.V } & \multicolumn{2}{|c|}{$\begin{array}{l}\text { No. of Panicles } \\
\text { plant }^{-1}\end{array}$} & \multicolumn{2}{|c|}{$\begin{array}{l}\text { Panicle length } \\
(\mathrm{cm})\end{array}$} & \multicolumn{2}{|c|}{$\begin{array}{c}\text { Panicle weight } \\
\text { (g) }\end{array}$} & \multicolumn{2}{|c|}{ Total grains /panicle ${ }^{-1}$} \\
\hline & 2015 & 2016 & 2015 & 2016 & 2015 & 2016 & 2015 & 2016 \\
\hline $\begin{array}{l}\text { Replication } \\
\text { Genotypes }\end{array}$ & $\begin{array}{c}0.65 \\
\text { ns }\end{array}$ & $0.02 \mathrm{~ns}$ & $\begin{array}{c}0.20 \\
\mathrm{~ns}\end{array}$ & $\begin{array}{c}0.09 \\
n s\end{array}$ & $\begin{array}{c}0.0005 \\
\mathrm{~ns}\end{array}$ & $\begin{array}{c}0.02 \\
n s\end{array}$ & $\begin{array}{l}0.17 \mathrm{~ns}^{*} \\
160592^{* *}\end{array}$ & $6.93 \mathrm{~ns}^{* *}$ \\
\hline Error & $\begin{array}{l}9.68^{* *} \\
0.42\end{array}$ & 0.10 & $\begin{array}{l}1.99^{* *} \\
0.09\end{array}$ & $\begin{array}{l}5.52^{* *} \\
0.07\end{array}$ & $\begin{array}{l}0.17^{* *} \\
0.002\end{array}$ & $\begin{array}{l}0.36^{* *} \\
0.01\end{array}$ & 1.63 & 3.93 \\
\hline $\begin{array}{l}\mathrm{H}_{2} \mathrm{~b} \\
\mathrm{C} . \mathrm{V}\end{array}$ & $\begin{array}{l}90.05 \\
3.62\end{array}$ & $\begin{array}{l}99.25 \\
1.63\end{array}$ & $\begin{array}{c}87.28 \\
1.29\end{array}$ & $\begin{array}{l}97.18 \\
1.19\end{array}$ & $\begin{array}{l}98.55 \\
0.96\end{array}$ & $\begin{array}{c}93.31 \\
1.58\end{array}$ & $\begin{array}{l}99.89 \\
0.79\end{array}$ & $\begin{array}{l}99.53 \\
1.15\end{array}$ \\
\hline
\end{tabular}

Data in Table (7) showed that, Giza 177 and Giza 178m gave higher 1000- grain weight than their parents in 2015 season, while, 2016 season all tested mutants surpassed their parents expect Sakha $104 \mathrm{~m}$ which gave nearly the same as its parent. As for seed set \% data revealed that all he tested mutants gave higher seed set \% than their parents in 2016 season, while, in 2015 season only Sakha $104 \mathrm{~m}$ produced greater seed set \% than its parent. Data in the same table 
indicated that all the mutants under study produced the greatest grain yield as compared with their parents in the two studied seasons expect Sakha $104 \mathrm{~m}$ which gave nearly the same grain yield. The same trend was observed with harvest index in the two studied seasons expect Sakha $101 \mathrm{~m}$ which gave nearly the same harvest index. The increases in grain yield of all the tested mutants than their parents might be due to the exchange in gene constitutions or structure as the results to $X$ rays treatments with their parents which cause an increase in root and vascular bundles diameter as well as umber of xylem vessels in the most of the mutants that improve both absorption of water and nutrients uptake from the soil to up ground part of plant (plant canopy). The continuous supply for plant by water and nutrients during the different stages cause an increase in all physiological process, such as photosynthesis and its products (assimilates) which translocate from source to sink consequently increase the filling rate and percentage resulted in increased weight of panicles, 1000- grain weight, number of filled grains and grain yield, these results were confirmed with those obtained by Shehzadet al (2011). They reported that, the results from yield trails indicated that the mutants differed genetically from their parents. Also, El-Degwy (2013) who found that, the measurements of variation were in general, higher in the treated plants compared with the control.

Table (7): Mean performance for yield characters of some rice cultivars and mutants that produced from X- rays treatment during 2015 and 2016 seasons

\begin{tabular}{|l|c|c|c|c|c|c|c|c|}
\hline \multirow{2}{*}{ Varieties } & \multicolumn{2}{|c|}{$\begin{array}{c}1000-\text { grain } \\
\text { weight }\end{array}$} & \multicolumn{2}{c|}{ Seed set (\%) } & \multicolumn{2}{c|}{ Grain yield plant } & \multicolumn{2}{c|}{$\begin{array}{c}\text { Harvest index } \\
(\%)\end{array}$} \\
\cline { 2 - 9 } & 2015 & 2016 & 2015 & 2016 & 2015 & 2016 & 2015 & 2016 \\
\hline Sakha 101 & 29.07 & 29.25 & 93.99 & 94.35 & 45.90 & 45.80 & 52.44 & 48.13 \\
Sakha 101M & 29.19 & 29.70 & 94.54 & 96.34 & 48.82 & 49.96 & 46.87 & 52.37 \\
Sakha 104 & 28.04 & 28.65 & 91.50 & 91.76 & 43.12 & 44.84 & 48.21 & 45.13 \\
Sakha 104M & 28.05 & 28.71 & 97.76 & 98.44 & 44.89 & 45.38 & 52.42 & 46.86 \\
Giza 177 & 28.25 & 28.91 & 96.32 & 96.19 & 44.19 & 43.08 & 44.89 & 43.10 \\
Giza 177M & 27.83 & 29.55 & 96.92 & 98.84 & 46.63 & 47.74 & 46.59 & 44.72 \\
Giza 178 & 21.42 & 21.50 & 95.18 & 94.37 & 46.99 & 45.06 & 47.96 & 52.11 \\
Giza 178M & 22.92 & 23.66 & 96.94 & 97.15 & 48.66 & 49.68 & 53.02 & 57.07 \\
\hline LSD 0.05 & 0.350 & 0.413 & 1.600 & 1.243 & 1.139 & 0.813 & 1.168 & 1.049 \\
\hline
\end{tabular}

Data in Table (8) showed that, highly significant differences among all varieties under study were found. The rice varieties recorded highly significant and differences values for 1000-grain weight, seed set \%, grain yield/plant and harvest index as well as, the heritability in broad sense which recorded the highest values for the yield characters. These results might be due to the differences in the genetic constitutions between the mutants and their parents although these characters didn't affect by environmental conditions. These 
results were confirmed with those obtained by Deng and Wu (1990) they found that, the mutants produced higher grain number/panicle and grain yield than their control were detected.

Table (8): Estimates of the mean square of yield characters of some rice cultivars and mutants that produced from X- rays treatment during 2015 and 2016 seasons

\begin{tabular}{|c|c|c|c|c|c|c|c|c|}
\hline \multirow{4}{*}{ S.O.V } & \multicolumn{8}{|c|}{ Yield Characters } \\
\hline & \multicolumn{8}{|c|}{ M.S } \\
\hline & \multicolumn{2}{|c|}{$\begin{array}{l}1000 \text {-grain } \\
\text { weight }(\mathrm{g})\end{array}$} & \multicolumn{2}{|c|}{ Seed set (\%) } & \multicolumn{2}{|c|}{ Grain yield plant } & \multicolumn{2}{|c|}{$\begin{array}{l}\text { Harvest index } \\
(\%)\end{array}$} \\
\hline & 2015 & 2016 & 2015 & 2016 & 2015 & 2016 & 2015 & 2016 \\
\hline Replicati & 0.09 & $0.02 \mathrm{~ns}$ & $0.12 \mathrm{~ns}$ & $0.33 \mathrm{~ns}$ & $0.63 n s$ & $0.25 n s$ & $0.36 n s$ & 0.64 \\
\hline & ns & $29.00^{* *}$ & $11.81^{*}$ & $16.64^{\star *}$ & $12.46^{\star *}$ & $51.33^{\star *}$ & $17.58^{*}$ & ns \\
\hline Genotyp & $26.18^{*}$ & 0.06 & * & 0.50 & 0.42 & 0.22 & * & $67.85^{*}$ \\
\hline & * & & 0.83 & & & & 0.44 & * \\
\hline Error & 0.04 & & & & & & & 0.35 \\
\hline $\mathrm{H}_{2} \mathrm{~b}$ & 99.51 & 99.72 & 92.55 & 95.25 & 92.23 & 99.09 & 95.65 & 98.56 \\
\hline C.V & 0.74 & 0.86 & 0.96 & 0.74 & 1.41 & 0.97 & 1.34 & 1.23 \\
\hline
\end{tabular}

There are significant positive correlation coefficients among diameter of root and each of tillers/plant, panicles/plant and seed set $\%$. On the other hand negative correlation was found with total grains/panicle. Epidermis thickness positively correlated with tillers/plant, panicles/plant and diameters of root while negatively correlation with panicle length, grains/plant, grain yield/plant and harvest index. Cortex thickness was positively correlated with tillers/plant, panicles/plant, seed set \%, diameter of root and epidermis thickness and negatively correlated with plant height. Vascular cylinder was positively correlated with tillers/plant, panicles/plant, 1000-grain weight, diameter of root, Epidermis thickness and cortex thickness while negatively correlated with grains/plant and harvest index. Meta xylem vessels were positively correlated with plant height and epidermis thickness while negatively correlated with harvest index. Finally, number of xylem vessels and panicle weight was positivity correlated as shown in Table (9). These results may be helpful the breeder to understanding the effect of $x$-rays on root structure of some rice cultivars. 
Table (9): Correlation Coefficient between Anatomical, Morphological and yield characteristics of some mutants of rice varieties treated by $\mathrm{X}$ - rays and their parents

\begin{tabular}{|c|c|c|c|c|c|c|c|c|c|c|c|c|c|c|c|c|c|}
\hline & PH & Ti/pl & $\mathrm{Ch}$ & $\operatorname{Pan} / \mathrm{PI}$ & $\mathrm{PL}$ & PW & To/P & Th & S.S & G.Y & H.I & $\varnothing r$ & $\begin{array}{l}\text { E.T } \\
(\mu)\end{array}$ & $\begin{array}{l}\text { C.T } \\
(\mu)\end{array}$ & V.C & $\begin{array}{l}\text { M.X.V } \\
(\varnothing)\end{array}$ & No.X.V \\
\hline D.H & $-0.484^{*}$ & -0.203 & $0.873^{\text {t* }}$ & -0.109 & $0.474^{* *}$ & 0.222 & 0.342 & -0.136 & -0.709 & $\begin{array}{l}-0.149 \\
\end{array}$ & 0.175 & -0.148 & -0.080 & -0.182 & -0.171 & -0.080 & 0.343 \\
\hline $\mathrm{PH}$ & & -0.150 & -0.324 & -0.320 & $\begin{array}{l}-0.697 \\
\end{array}$ & $-0.612^{\star *}$ & -0.612 & -0.174 & -0.111 & $-0.647^{* \star}$ & $0.442^{*}$ & -0.380 & 0.244 & $0.423^{* *}$ & -0.228 & $0.427^{*}$ & -0.329 \\
\hline $\begin{array}{l}T / p l \\
\end{array}$ & & & -0.347 & $0.900^{* *}$ & $-0.420^{\star}$ & $-0.415^{*}$ & $-0.444^{\star}$ & 0.228 & $0.480^{*}$ & 0.059 & -0.301 & $0.584^{* *}$ & $0.444^{*}$ & $0.588^{* *}$ & $0.662^{* *}$ & -0.117 & -0.213 \\
\hline Ch & & & & $\begin{array}{l}0.196 \\
\end{array}$ & $0.712^{* *}$ & 0.108 & 0.349 & -0.208 & $-0.792^{* *}$ & -0.220 & 0.180 & $\begin{array}{r}-0.171 \\
\end{array}$ & $\begin{array}{r}-0.091 \\
\end{array}$ & -0.155 & $\begin{array}{l}-0.298 \\
\end{array}$ & -0.017 & 0.212 \\
\hline $\begin{array}{c}\mathrm{Pan} / \\
\mathrm{PI}\end{array}$ & & & & & -0.255 & -0.374 & -0.481 & 0.341 & $0.417^{\star}$ & 0.165 & -0.326 & $0.820^{* \star}$ & $0.586^{* *}$ & $0.801^{\star *}$ & $0.768^{* *}$ & 0.037 & -0.392 \\
\hline $\mathrm{PL}$ & & & & & & $0.674^{* *}$ & 0.379 & 0.0 .30 & -0.496 & $\begin{array}{l}0.399 \\
\end{array}$ & $\begin{array}{l}0.464 \\
\end{array}$ & -0.150 & $-0.451^{\star}$ & -0.116 & $\begin{array}{l}-0.263 \\
\end{array}$ & -0.140 & 0.334 \\
\hline PW & & & & & & & 0.574 & -0.169 & 0.076 & $0.757^{* *}$ & $0.786^{* *}$ & -0.241 & $0.753^{* *}$ & -0.179 & -0.306 & -0.322 & $0.406^{*}$ \\
\hline To/P & & & & & & & & $-0.876^{\star *}$ & 0.244 & 0.201 & $0.864^{* *}$ & $-0.442^{*}$ & $0.599^{* *}$ & $\begin{array}{l}-0.383 \\
\end{array}$ & $-0.486^{*}$ & $\begin{array}{l}-0.233 \\
\end{array}$ & 0.304 \\
\hline Th & & & & & & & & & 0.134 & 0.125 & -0.652 & 0.379 & 0.354 & 0328 & $0.427^{*}$ & 0.214 & -0.181 \\
\hline S.S & & & & & & & & & & $0.414^{*}$ & 0.057 & $0.429^{\star}$ & 0.010 & $0.469^{*}$ & 0.315 & -0.367 & 0.008 \\
\hline G.Y & & & & & & & & & & & $0.581^{\text {t* }}$ & 0.242 & $-0.440^{*}$ & 0.312 & 0.070 & -0.138 & -0.037 \\
\hline H.I & & & & & & & & & & & & -0.328 & $0.798^{* *}$ & -0.228 & $-0.484^{*}$ & $-0.457^{\star}$ & 0.400 \\
\hline$\varnothing \mathrm{r}$ & & & & & & & & & & & & & $0.682^{* *}$ & $0.982^{* *}$ & $0.771^{* *}$ & 0.171 & -0.490 \\
\hline $\begin{array}{l}\text { E.T } \\
(\mu)\end{array}$ & & & & & & & & & & & & & & $0.591^{* *}$ & $0.741^{* *}$ & $0.560^{* *}$ & -0.645 \\
\hline $\begin{array}{l}\text { C.T } \\
(\mu)\end{array}$ & & & & & & & & & & & & & & & $0.671^{\text {** }}$ & 0.089 & -0.454 \\
\hline V.C & & & & & & & & & & & & & & & & 0.311 & -0.438 \\
\hline $\begin{array}{c}\text { M.X. } \\
\text { V. } \\
(\varnothing)\end{array}$ & & & & & & & & & & & & & & & & & -0.866 \\
\hline
\end{tabular}

D.H: Days to heading Chlorophyll content No. total grains per panicle yield / plant H.I: Harvest P.H: Plant height $\mathrm{PI}$ : Panicle length Th: 1000 grain weight Ti/PI: No. of tiller per plant P.W: Panicle weight S.S: Seed set \% Ch: To/P: G.Y: Grain Co.T: Cortex tissue thickness Ør: Diameter of root Ep.T: Epidermis Thickness No.XV = Number of Xylem Vessels 
A

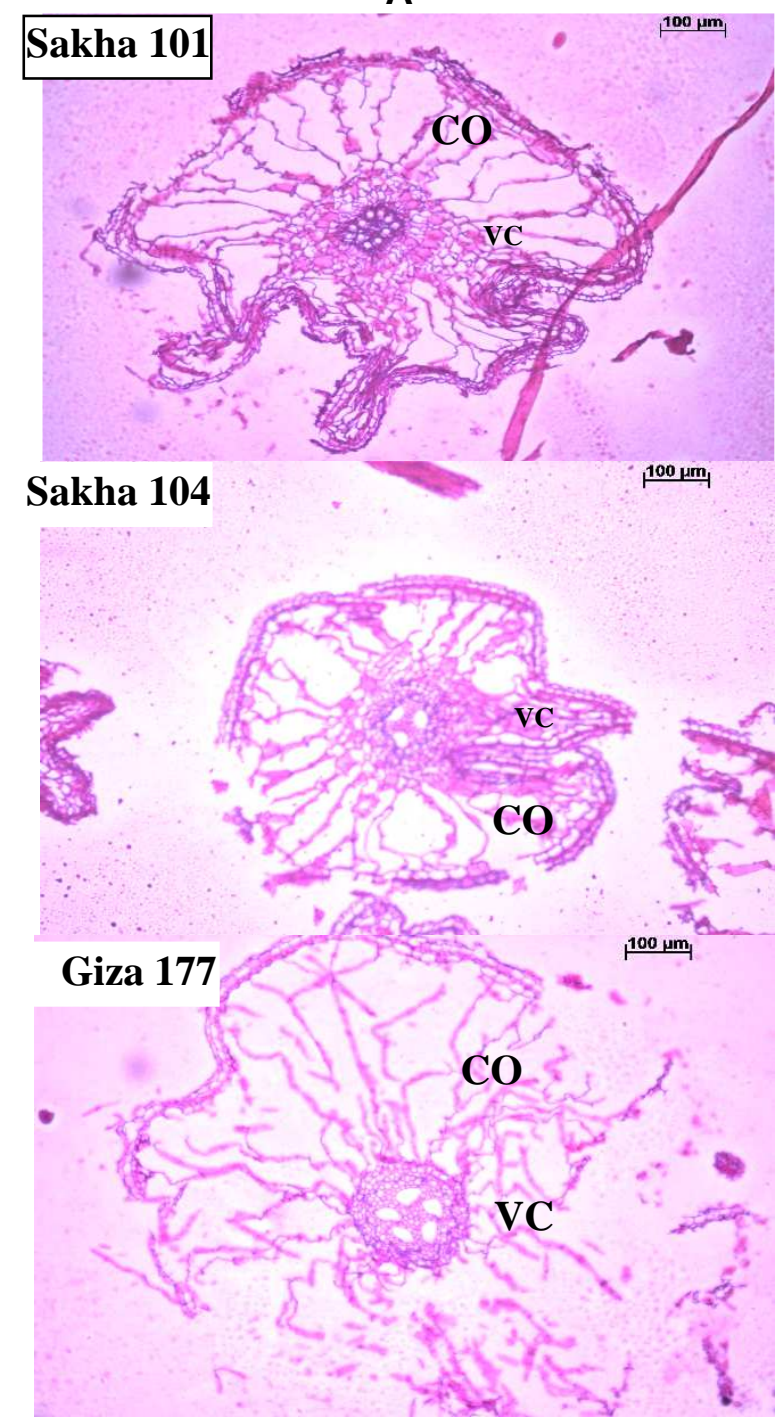

B

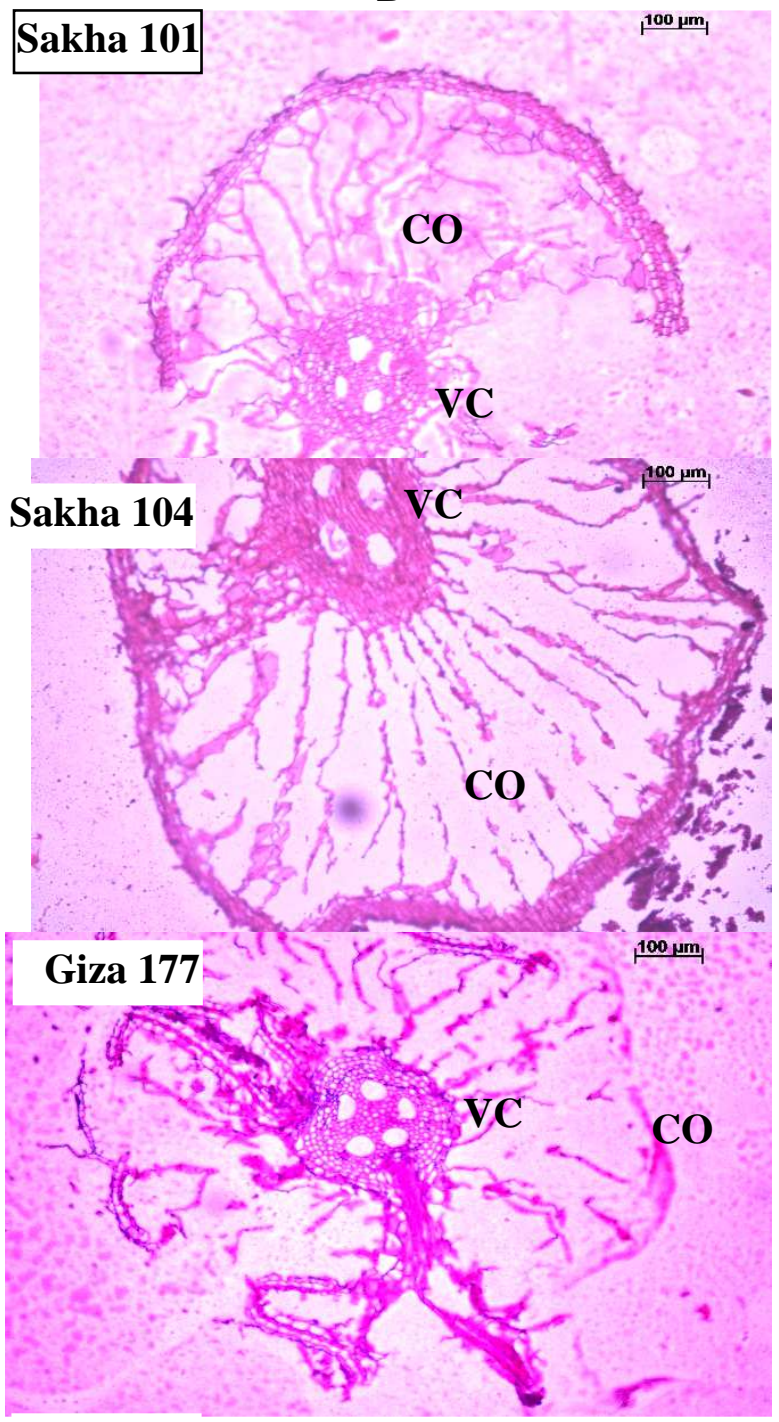

Giza 178 
Giza 178

\section{CO}

\section{$\mathrm{VC}$}

$100 \mu \mathrm{m}$

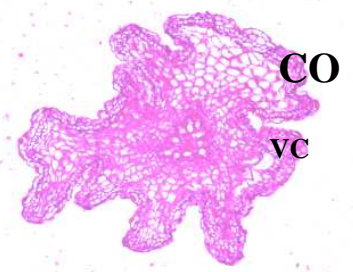

Fig (1): transfer sections in roots of some rice varieties at 35 days from sowing date (A) not treated, (B) treated with $X$ - rays (350 Kr), (X 100) Bar $=100 \mu \mathrm{m}, \mathrm{CO}=$ Cortex tissue and $\mathrm{VC}=$ Vascular cylinder

\section{REFERENCE}

Akbar, A. and B. Manzoor (2003). Radio sensitivity studies in basmati rice. Pak.J.Bot., 35(2): 197-207.

Denisem. D. (2003).Effects of submergence and hypoxia on the growth and anatomy of rice (Oryza sativa L.) seedling, PhD .Dept. plant biology Fac.of Louisiana state Univ.

Deng, D.S.and W. Wu (1990). Early mutant "Fu-06" used for hybrid rice breeding. New letter 27:6.

Elayaraja,K., M. Prakash, K. Saravanan, S. B. Kumar and J. Ganesen (2005) Studies on variability, heritability and genetic advanced for certain quantitative characters in mutant populationof rice (Oryza sativa L.) Crop Research- Hisar, 1: 134-137.

EI Degwey, I. S., (2013). Mutation induced genetic vaiability in rice (Oryza Sativa L., ). International journal of Agriculture and Crop Sciences.5-23/2789-2794.

EI Emery, F. A., M.I. Abo Youssef and I. A. Talha (2015). Growth, Yield and its traits, chemical and anoatomical structure as indicator to effect of GA3 application on some rice genotypes (Oryza Sativa L.). J. Agric. Res. KafrElsheikhUniv..41(4) 1235-1250.

Fujii, T., Matsumura S. (1958). Radiosensitivity in plant. 1, Detemination of LD-50 in cultivated plants.Jap. J. Genetics 33:389-397

Gerlach, D. (1977). Botanshemicotechnik.Eineeinfuhrungtheimeveriag, Stuttgart.BRO..

Hammad, D.H.A. and I.H. EL-Geddawi (1988).Effect of gamma irradiation on yield and chemical constituents of sugar beet. Paper presented at the fourth conf. of Nuclear Sciences and application 6-10 March.

IRRI (1998). Standard Evaluation System for rice 3rd Edition, International Rice Testing Programm.

Kawata, S., S. Morita, and Yamazakik (1979). Study on the number of vessels and sieve tubes in grown roots of rice plants. JPN J. Crop. Sci. 48, 502-509. 
Khin, T. (2006) Rice mutant breeding for varietals improvement in Myanmar.PI. Mut. Rep., 1(1) 34-36.

Mohamad, O., Mohd.Nazir, B., Alias, I., Azlan, S., Abdul Rahim, H., Abdullah, M.Z. Othman, O., Hadzim, K., Saad, A., H. Habibuddin and F. Golam (2006). Development of improved rice varieties through the use of induced mutations in Malaysia. Plant Mut. Rep., 1:27-34.

Pialli, M.A., M. Subramanian and S. Murugan(1993). Effectiveness and efficiency of gamma rays and EMS for chlorophyll mutation on up land rice. Annals of Agricultural Research 14 (3): 302-305.

RRTC- proceeding (2014). Proceeding of the 10 th National program work shop final results of (2013).

RRTC- proceeding (2015). Proceeding of the 10 th National program work shop final results of (2014) .

Sabbour, A.M., A. A. Mohamed and M.A. Kattab (1993)Radiosensetivity of two rice varieties treated with gamma rays. Bulletin of Fac. Of Agric., Cairo Univ., 44(3):663-684.

Shehzad, T., A.A. Abdallah, M.H. Amar and A. F. Abdelkhalik(2011). Agronomic and molecular evaluation of induced mutant rice (Oryza sativa L. ) lines in Egypt. Pak. J. Bot., 43(2): 1183-1194.

Soomro, A.M., M.H. Naqvi, H.R. Bughio and M.S. Bughio (2006) Sustainable enhancement of rice production through the use mutation breeding . Plant Mut. Rep., 1: 13-17.

Sanjeev, S.(2000). Gamma-rays induced genetic variability in M1 and M2 populations of rice (Oryza sativa L.). Advances in parent sciences 6 (1): 24-33.

Steel, R.C.D., and J.H. Torrie (1980). Principles and procedures of statistics $2^{\text {nd }}$ ed. Mc Graw- Hill, New York.

Wu, J.L., C. Lei, M. Baraoidan, A. Bordeos, M.R.S. Madamba, M. Ramos, R. Mauleon, A.Portugal, V.J. Ulat and R. Bruskiewich (2005) Chemical and irradiation induced mutants of indica rice IR64 for forward and reverse genetics. Plant Mol. Bio., 59:85-97.

$$
\begin{aligned}
& \text { الصفات التشريحية والمورفولوجية والمحصولية لبعض أصناف الأرز المعاملة } \\
& \text { بالأشعة السينية (X-rays) }
\end{aligned}
$$

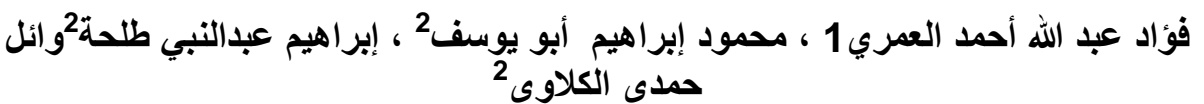

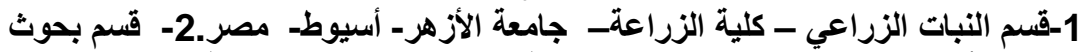

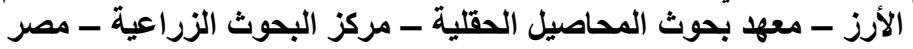

$$
\begin{aligned}
& \text { الملخص العربي }
\end{aligned}
$$

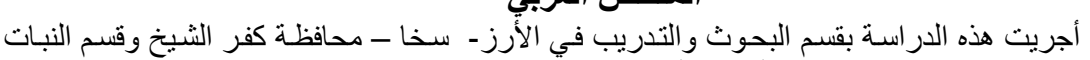

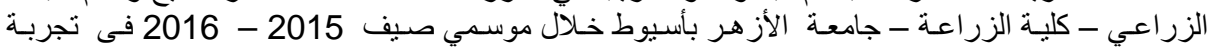

$$
\begin{aligned}
& \text { لقطاعات كاملة العشو ائية فى ثلاث مكررات لدراسة أثر أستخدام الأشعة السينية (x-rays) بمعدل } 350 \text { كيلو }
\end{aligned}
$$




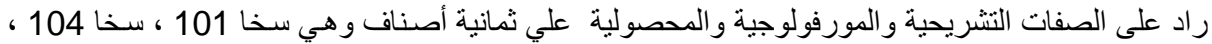

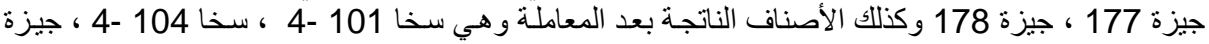
177 -4 ، جيزة 177 ، 178-4 وذللك وقد سجلت البيانات النالية:-

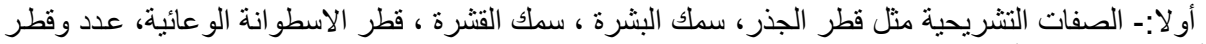

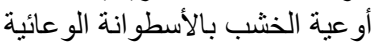

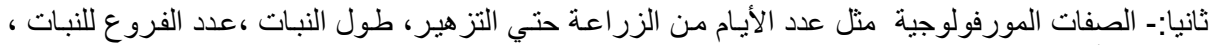

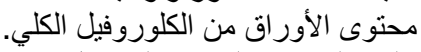

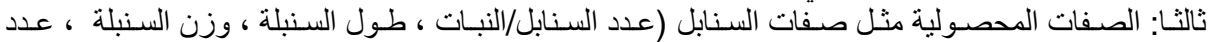

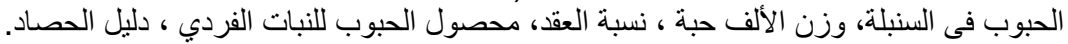

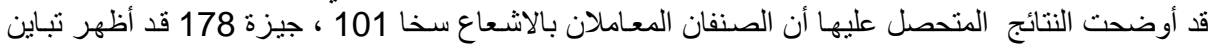

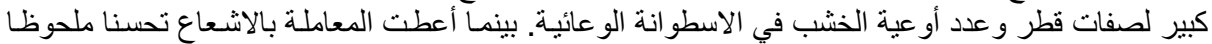

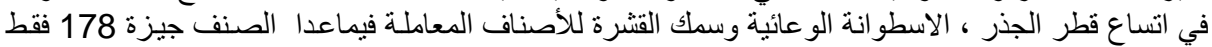

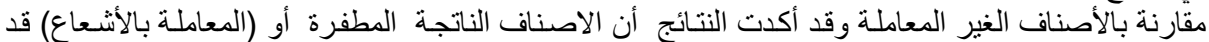

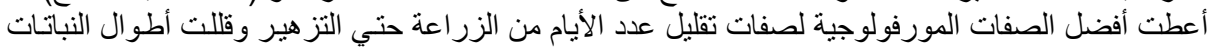

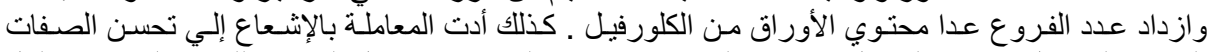

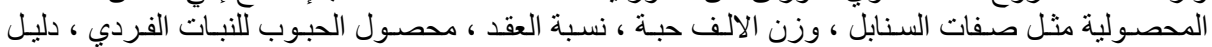

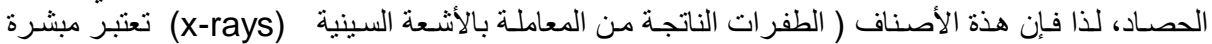

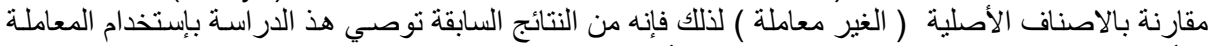

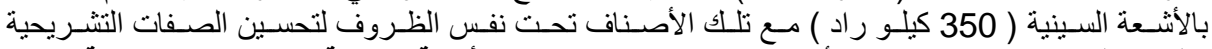

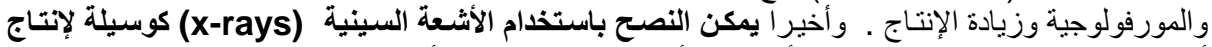

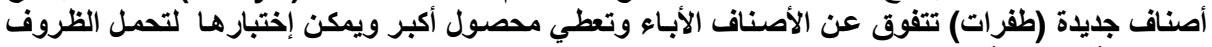

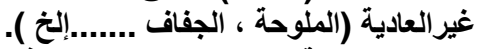
* الكلمات الدالة :التركيب التشريحي للجذور - أصناف الأرز - الآثثعاع. 